\title{
SISTEM PENDAFTARAN TANAH SISTEMATIS LENGKAP PADA BADAN PERTANAHAN NASIONAL (BPN) KOTA PALEMBANG
}

\author{
${ }^{1}$ Rahayu Amalia, ${ }^{2}$ Imam Solikin \\ ${ }^{1}$ Program Studi Sistem Informasi, Fakultas Ilmu Komputer \\ ${ }^{2}$ Program Studi Manajemen Informatika, Fakultas Vokasi \\ Universitas Bina Darma, Jalan Jendral A. Yani No.03, Palembang Kode Pos 30111, Indonesia \\ Email: rahayuamalia@binadarma.ac.id, imamsolikin@binadarma.ac.id
}

(Diterima: 25 Maret 2019, direvisi: 6 Agustus 2019, disetujui: 13 Agustus 2019)

\begin{abstract}
ABSTRAK
Badan Pertanahan Nasional (BPN) Kota Palembang beralamat di Jalan Kapten A. Rivai No. 99 Palembang, BPN merupakan salah satu instansi pemerintah yang menangani pemohonan sertifikat Pendaftaran Tanah Sistematis Lengkap (PTSL). Permasalah yang dihadapi karyawan BPN dalam Pemohon sertifikat PTSL yaitu pada bagian pendataan yang masih menggunakan Microsoft Word dan Microsoft excel bahkan ada data yang masih ditulis di kertas untuk rekap data hal tersebut menjadikan pekerjaan menjadi kurang efektif dan efesien karena kesuliatan dalam pendataan, pencarian data sampai kersulitan dalam pembuatan laporan. Solusi dari permasalah tersebut dengan memanfaatkan kemajuan teknologi untuk mendukung kinerja karyawan, dengan membangun sistem PTSL berbasis teknologi informasi. Metode pengembangan sistem yang digunakan adalah linier sequensial model dengan beberapa tahap yang dilakukan antara lain formulasi, perencanaan, analisis, rakayasa, implementasi dan pengujian, dan evaluasi. Tujuan dari penelitian ini adalah membangun sistem pendataan pemohon sertifikat PTSL pada BPN yang dapat memudahkan karyawan pekerja tidak tetap (PTT) dalam melakukan penginputan dan pencarian data sehingga dapat meningkatkan kinerja kerja karyawan PTT di BPN Kota Palembang.
\end{abstract}

Keywords: BPN, PTSL, linier sequensial model

\section{PENDAHULUAN}

Badan Pertanahan Nasional (BPN) Kota Palembang merupakan salah satu instansi pemerintah yang beralamat di Jl. Kapten A. Rivai No. 99 Palembang, instanasi ini salah satu yang menerapkan program baru berupan Pendaftaran Tanah Sistematis Lengkap (PTSL). "PTSL adalah proses pendaftaran tanah untuk pertama kali, yang dilakukan secara serentak dan meliputi semua obyek pendaftaran tanah yang belum didaftarkan di dalam suatu wilayah desa atau kelurahan atau nama lainnya yang setingkat dengan itu. Melalui program ini, pemerintah memberikan jaminan kepastian hukum atau hak atas tanah yang dimiliki masyarakat. Metode PTSL ini merupakan inovasi pemerintah melalui Kementerian ATR/BPN untuk memenuhi kebutuhan dasar masyarakat: sandang, pangan, dan papan. Program tersebut dituangkan dalam Peraturan Menteri No 12 tahun 2017 tentang PTSL dan Instruksi Presiden No 2 tahun 2018" [1]. "Setelah munculnya Undang-Undang Nomor 5 Tahun 1960 tentang Peraturan Dasar Pokok-Pokok Agraria, banyak peraturan lain yang muncul seperti UndangUndang Nomor 21 Tahun 1997 tentang Bea Perolehan Hak Atas Tanah dan Bangunan, Ketetapan Majelis Permusyawaratan Rakyat Republik Indoneisa Nomor IX/MPR/2001 tentang Pembaruan Agraria dan Pengelolaan Sumber Daya Alam" [2]. "Badan Pertanahan Nasional (BPN) dibentuk berdasarkan Keputusan Presiden Republik Indonesia Nomor 26 Tahun 1988 sebagai Peningkatan dari Direktorat Jenderal Agraria Departemen Dalam Negeri, dan merupakan suatu Lembaga Pemerintah non Departemen (LPND) yang berkedudukan dibawah dan bertanggung jawab langsung setelah munculnya Undang-Undang Nomor 5 Tahun 1960 tentang Peraturan Dasar Pokok-Pokok Agraria, banyak peraturan lain yang muncul seperti Undang-Undang Nomor 21 Tahun 1997 tentang Bea Perolehan Hak Atas Tanah dan Bangunan, Ketetapan Majelis Permusyawaratan Rakyat Republik Indoneisa Nomor IX/MPR/2001 tentang Pembaruan Agraria dan Pengelolaan Sumber Daya Alam. Badan Pertanahan Nasional (BPN) dibentuk berdasarkan Keputusan Presiden Republik Indonesia Nomor 26 Tahun 1988 sebagai Peningkatan dari Direktorat Jenderal Agraria Departemen Dalam Negeri, dan merupakan suatu Lembaga Pemerintah non Departemen (LPND) yang berkedudukan dibawah dan bertanggung jawab langsung" [3]. 
Pada sistem pendaftaran, pemohon sertifikat PTSL ini harus menyerahkan berkas atau persyaratan berupa, KTP, Kartu Kelarga (KK), Surat Tanah, dan Pajak Bumi dan Bangunan (PBB) kekantor lurah masing-masing. "Sistem merupakan rangkaian dari dua atau lebih komponen-komponen yang saling berhubungan, yang berinteraksi untuk mencapai suatu tujuan" [4]. "Sistem merupakan serangkaian bagian yang saling tergantung dan bekerja sama untuk mencapai tujuan tertentu" [5]. "Sistem merupakan suatu jaringan prosedur yang dibuat menurut pola yang terpadu untuk melaksanakan kegiatan pokok perusahaan" [6]. Berdasarkan penjelasan diatas sistem merupakan serangkaian dari komponen-komponen yang saling tergantung yang mempunyai tujuan tertentu dan untuk melaksanakan kegiatan pokok perusahaan. Setelah itu berkas para pemohon akan diberikan kepada kantor BPN melalui perwakilan dari kelurahan, kemudian berkas-berkas tersebut diolah dibagian pendaftaran hak tanah. Pada bagian pendaftaran hak tanah [7] ini data atau berkas-berkas pemohon sertifikat PTSL dikelolah oleh karyawan Pekerja Tidak Tetap (PTT). Sistem pengelolahan tersebut masil dimakukan secara manual (menggunakan Microsoft Word dan Microsoft excel dan kadang masih ditulis tangan pada kertas dalam merekap data. Hal seperti ini mengakibatkan banyak pemohon sertifikat PTSL yang belum terdaftar karena ada data dan berkas yang hilang.

Berdasarkan uraian diatas, maka soslusi yang diambil peneliti yaitu dengan membangun sistem PTSL berbasis teknologi. Tujuan dari sistem yang dibangun ini adalah untuk mempermudah karyawan PTT dalam memproses PTSL, untuk mempermudah dalam pemcarian data, dan untuk meningkatkan kinerja karyawan PTT pada BPN Kota Palembang.

\section{TINJAUAN PUSTAKA}

Penelitian-penelitian terkait yang dijadikan sumber referensi dalam penelitian ini antara lain penelitian dengan judul artikel "Pengembangan aplikasi layanan pertanahan berbasis web pada Kantor BPN (Badan Pertanahan Nasional) Kabupaten Badung" [7] Adapun perbedaan penelitian menurut (Sofyan dkk) dengan penelitian yang berjalan adalah objek penelitianya, di Badan Pertanahan Nasional (BPN) Kabupaten Badung dan dilakukan pada Badan Pertanahan Nasional (BPN) Kota Palembang. Adapun persamaannya yaitu untuk mempermudah mendapatkan informasi pertanahan, pendaftaran atas tanah (sertifikat), informasi status akhir proses pembuatan sertifikat dan informasi tanah secara detail sebelum sertifikat tanah diakui secara hukum.

Penelitian selanjutnya yang dijadikan sumber referensi yaitu artikel dengan judul "Aplikasi permohonan surat izin tempat usaha berbasis web di Kantor Kelurahan" [8], dan "Sistem informasi pelayanan izin mendirikan bangunan dan peruntukan penggunaan tanah pada badan penanaman modal dan pelayanan perizinan Kabupaten Sumedang" [9]. Pada penelitian menurut (Bahram dkk) dan menurut (Waspodo dkk) mempunyai keterkaitan tentang sistem permohonan dan merupakan sistem berbasis web, adapun perbedaanya adalah sistemnya digunakan untuk permohonan izin pendirian bangun, sedangkan yang dilakukan merupakan pemohon untuk pengajuan sertifikat tanah. Penelitian tentang sistem sertifikasi tanah juga pernah dibahas pada penelitian [10] dengan objek penelitian berbeda dengan penelitian yang dilakukan yang menitik beratkan pada permohonan sertifikat tanah. Pada penelitian [11] juga dijadikan sebagai rujukan yang menitik beratkan pada bagian proses pendataan.

\section{METODE PENELITIAN}

\subsection{Metode Pengembangan Sistem}

Model waterfall merupakan model klasik yang bersifat sistematis, berurutan dalam membangun software [12]. Waterfall ini harus menyelesaikan tahap demi tahap untuk berlanjut ketahap selanjutnya dan berjalan berurutan. Fase-fase dalam waterfall model dapat dilihat pada Gambar 1. Adapun fase-fase model waterfall adalah:

1. Communication (Project Initiation \& Requirements Gathering)

Pada tahap ini dilakukan analisis permasalahan yang dihadapi melalui pengumpulan data menggunakan teknik observasi dan interview [13].

2. Planning (Estimating, Scheduling, Tracking)

Tahap ini dilakukan perancangan menggunakan activity diagram dan entity relationship diagram (ERD). 
3. Modeling (Analysis \& Design)

Pada tahap ini dilakukan perancangan tampilan interface,

4. Construction (Code \& Test)

Tahap ini menghasilkan suatu sistem pendaftaran tanah sistematis lengkap yang dibangun menggunakan bahasa pemrograman PHP dan MySql sebagai databasenya. Interface yang dihasilkan antara lain form permohonan pendaftaran sertifikat tanah. Pada juga dilakukan pengujian yang berfokus pada sistem pendaftaran tanah sistematis lengkap dari segi internel logis dari perangkat lunak, memastikan bahwa semua pernyataan sudah diuji. Tujuan dilakukan testing untuk menghindari error dan memastikan sistem yang dibangun berfungsi secara maksimal.

5. Deployment (Delivery, Support, Feedback)

Tahapan deployment merupakan tahapan implementasi software ke customer.

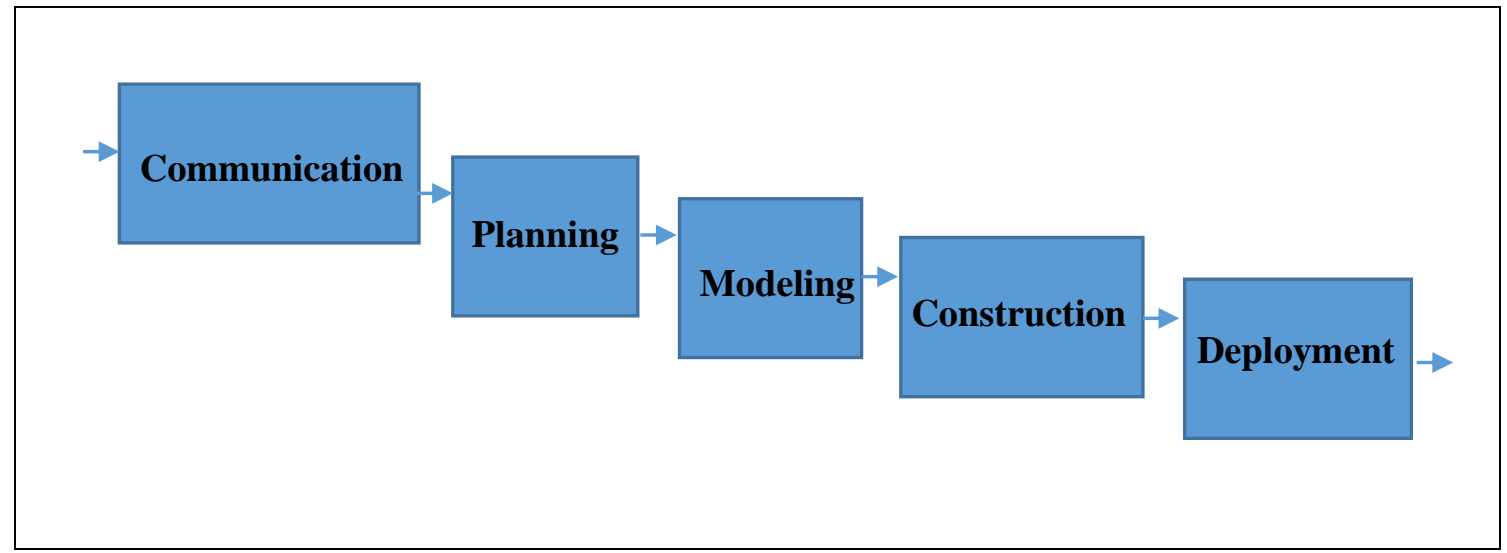

Gambar 1 Waterfall pressman (Pressman, 2015)

\section{HASIL DAN PEMBAHASAN}

\subsection{Communication}

Pada tahan ini dilakukan pengumpulan data dengan teknik pengumpulan data yang digunakan antara lain teknik observasi yang dilakukan di Kantor BPN Kota Palembang untuk mengamati secara langsung tentang pelaksanaan dari kegiatan operasional yang dilakukan di Kantor BPN Kota Palembang. Teknik interview yang dilakuakan kepada Pekerja Tidak Tetap (PTT) dikantor BPN mengenai: sistem Pendaftaran Tanah Sistematis Lengkap (PTSL), Syarat-syarat yang diperlukan untuk menjadi pemohon sertifikat PTSL, proses atau tahap-tahap pembuatan Sertfikat PTSL.

\subsection{Planning}

Desain yang digunakan untuk mengGambarkan alur sistem yaitu activity diagram dan entity relationship diagram (ERD)

1. "Activity Diagram merupakan diagram yang bersifat dinamis. Activity diagram dibuat berdasarkan aliran dasar dan aliran alternatif pada skenario use case diagram. Pada activity diagram digambarkan interaksi antara aktor pada use case diagram dengan sistem [14].

a. Activity diagram publik

Activity diagram publik menjelaskan pilihan-pilihan aktivitas yang dapat dilakukan oleh pengunjung web yang dapat dilihat pada Gambar 2.

b. Activity Diagram Administrator

Activity diagram administrator menjelaskan pilihan-pilihan aktivitas yang dapat dilakukan oleh administrator yang dapat dilihat pada Gambar 3.

c. Activity diagram Pekerja Tidak Tetap (PTT)

Activity diagram PTT menjelaskan pilihan-pilihan aktivitas yang dapat dilakukan oleh PTT yang dapat dilihat pada Gambar 4. 


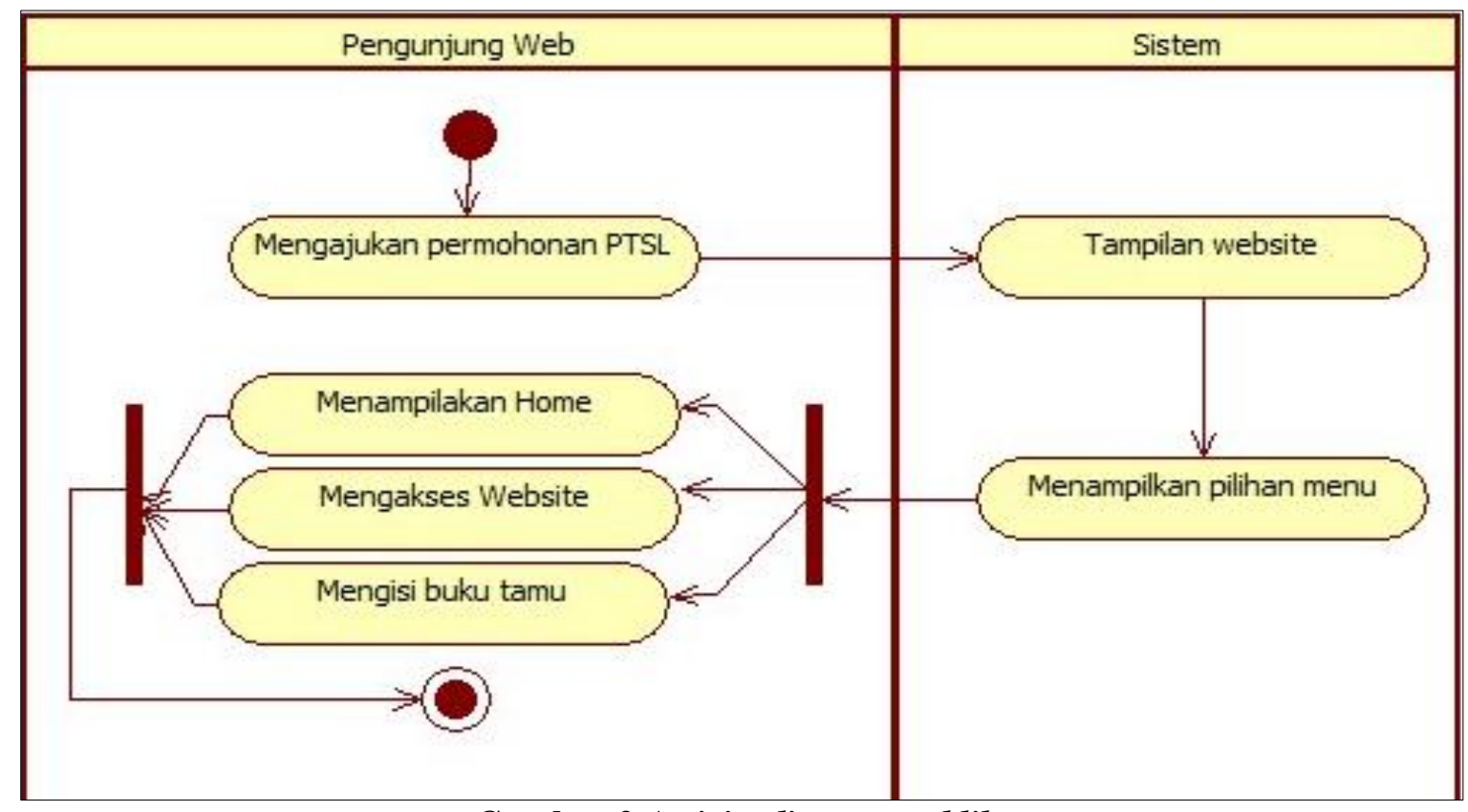

Gambar 2 Activity diagram publik

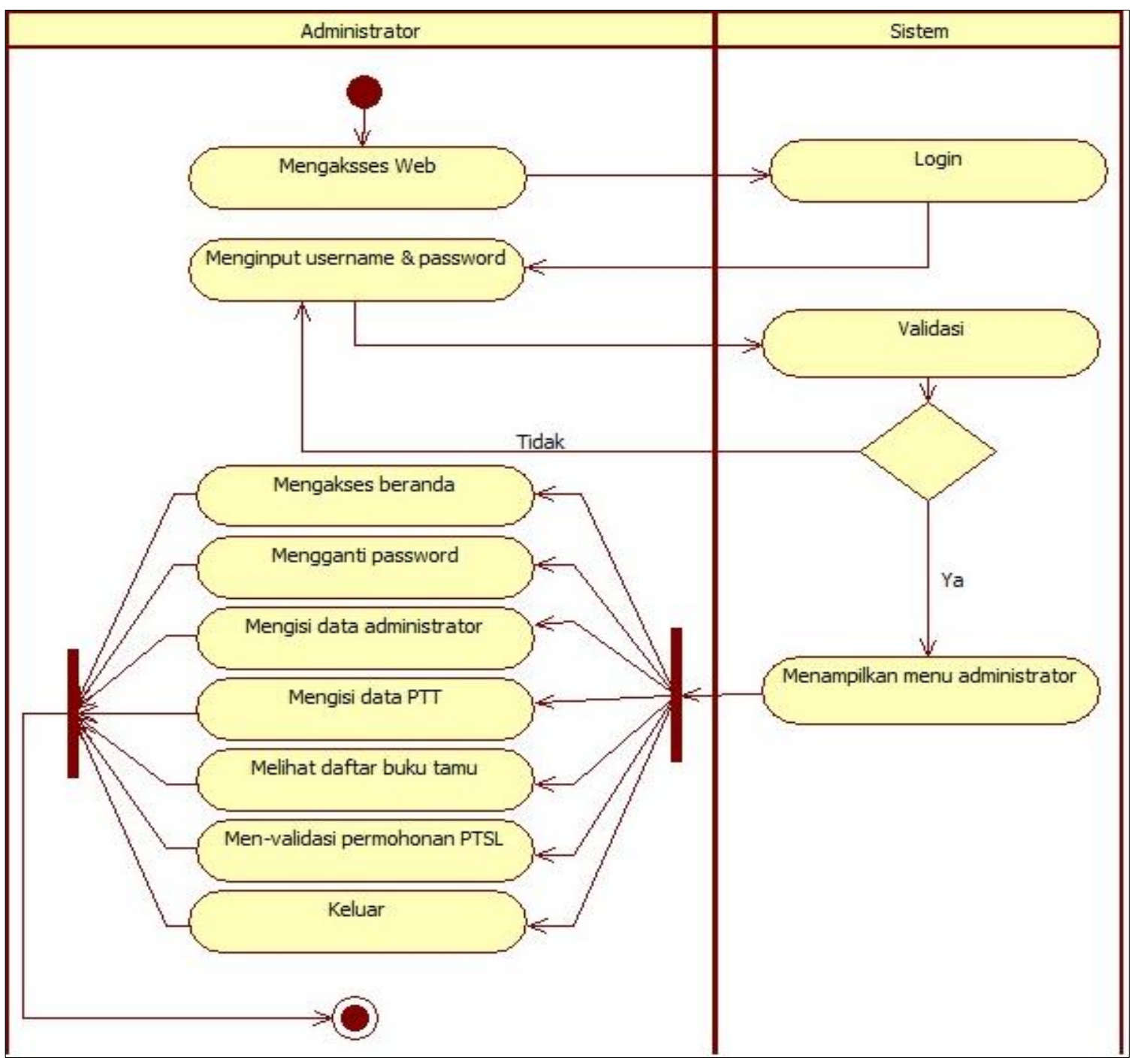

Gambar 3 Activity diagram administrator

Amalia, Sistem Pendaftaran Tanah Sistematis Lengkap Pada Badan Pertanahan Nasional (BPN) Kota Palembang 


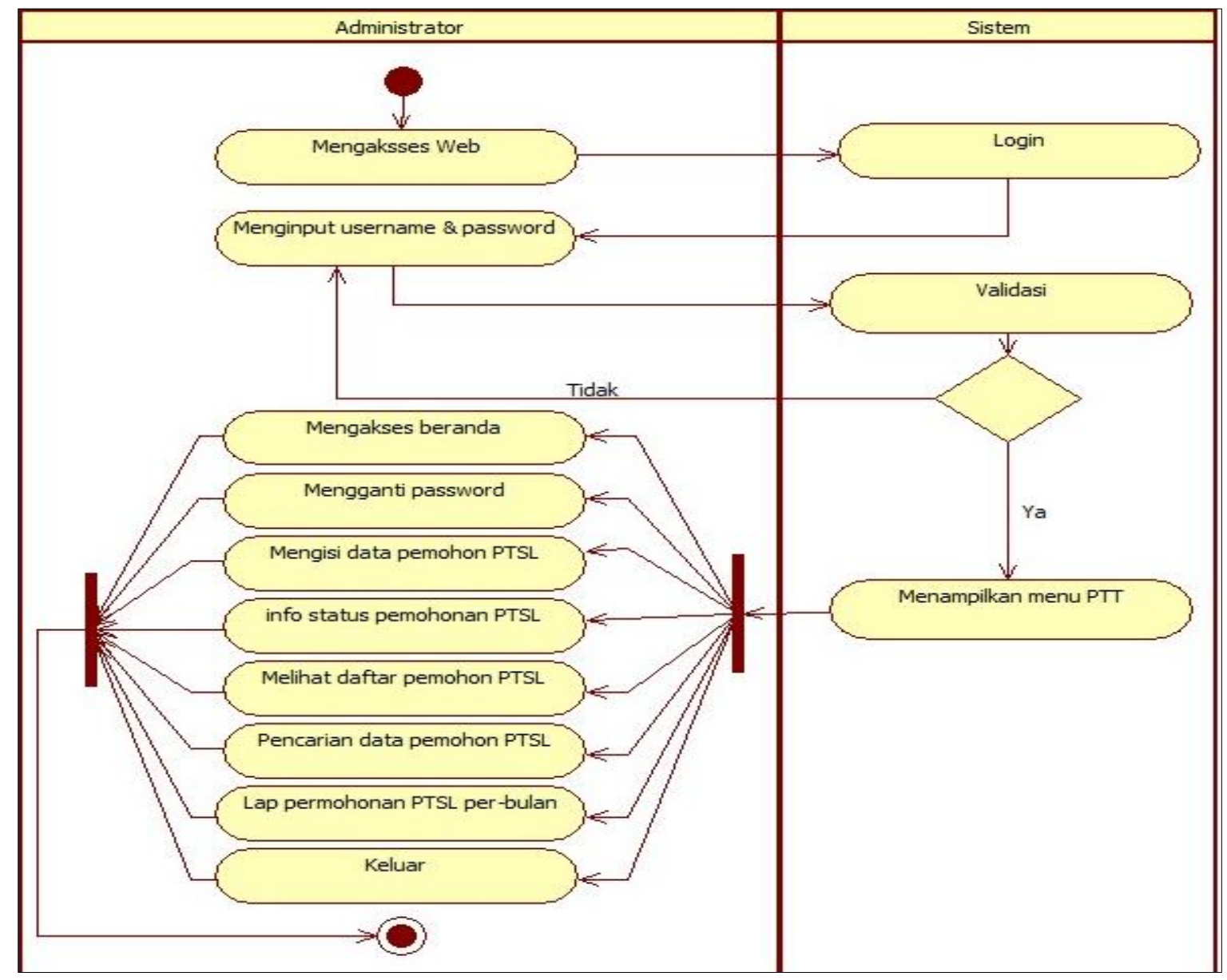

Gambar 4 Activity diagram pekerja tidak tetap (PTT)

d. Entity Relationship Diagram (ERD)

Entity Relationship Diagram (ERD) [15] adalah diagram yang mencoba mengGambarkan hubungan antar entitas-entitas dalam database. ERD disajikan pada Gambar 5.

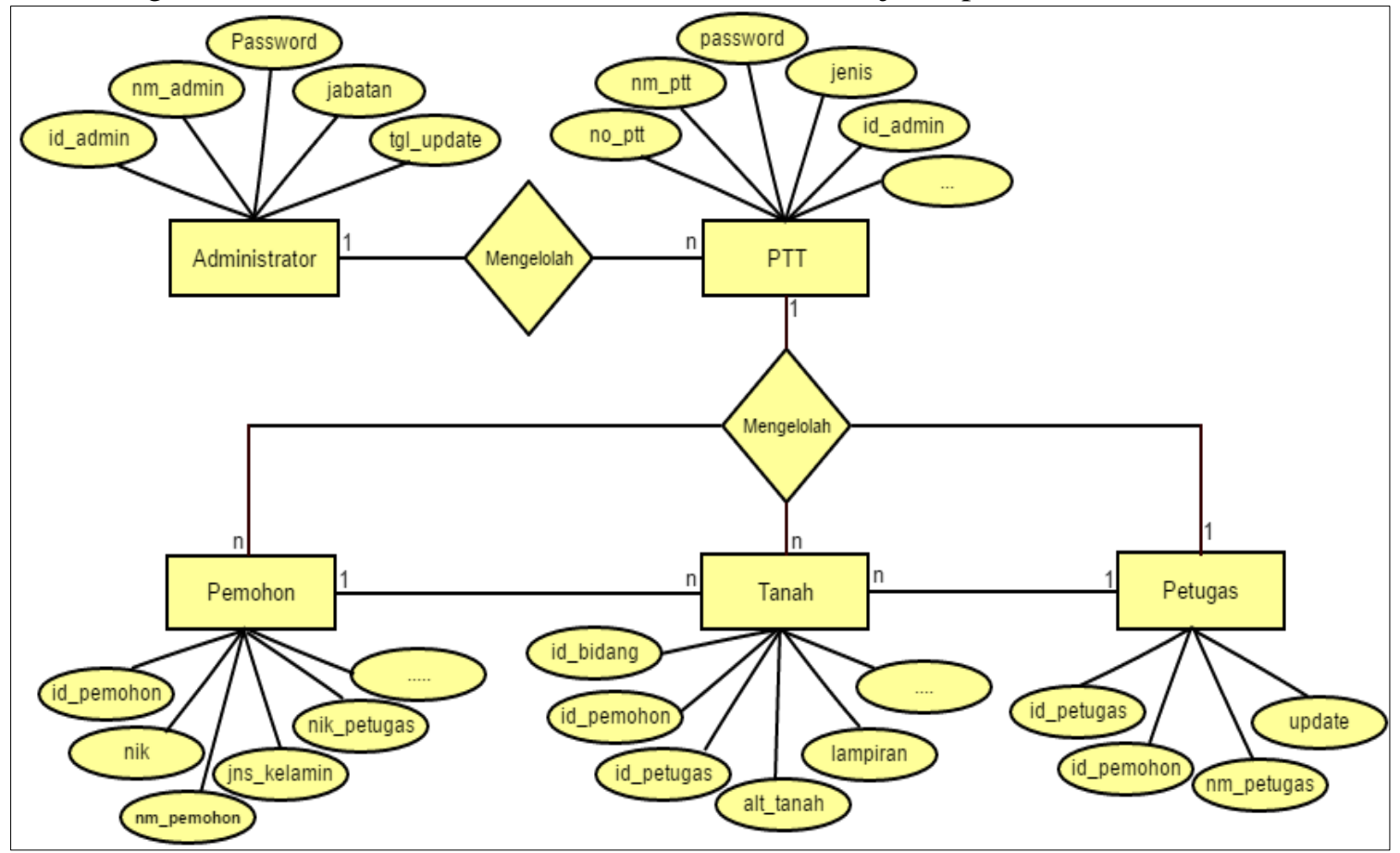

Gambar 5 Entity relationship diagram

Amalia, Sistem Pendaftaran Tanah Sistematis Lengkap Pada Badan Pertanahan Nasional (BPN) Kota Palembang 


\subsection{Modeling}

Pada tahap ini merupakan hasil terjemahan desain dalam bahasa yang dapat dibaca oleh mesin, hasil tersebut berupa interface dari sistem pendataan PTSL BPN kota Palembang

1. Interface daftar pemohon PTSL, dapat dilihat pada Gambar 6.

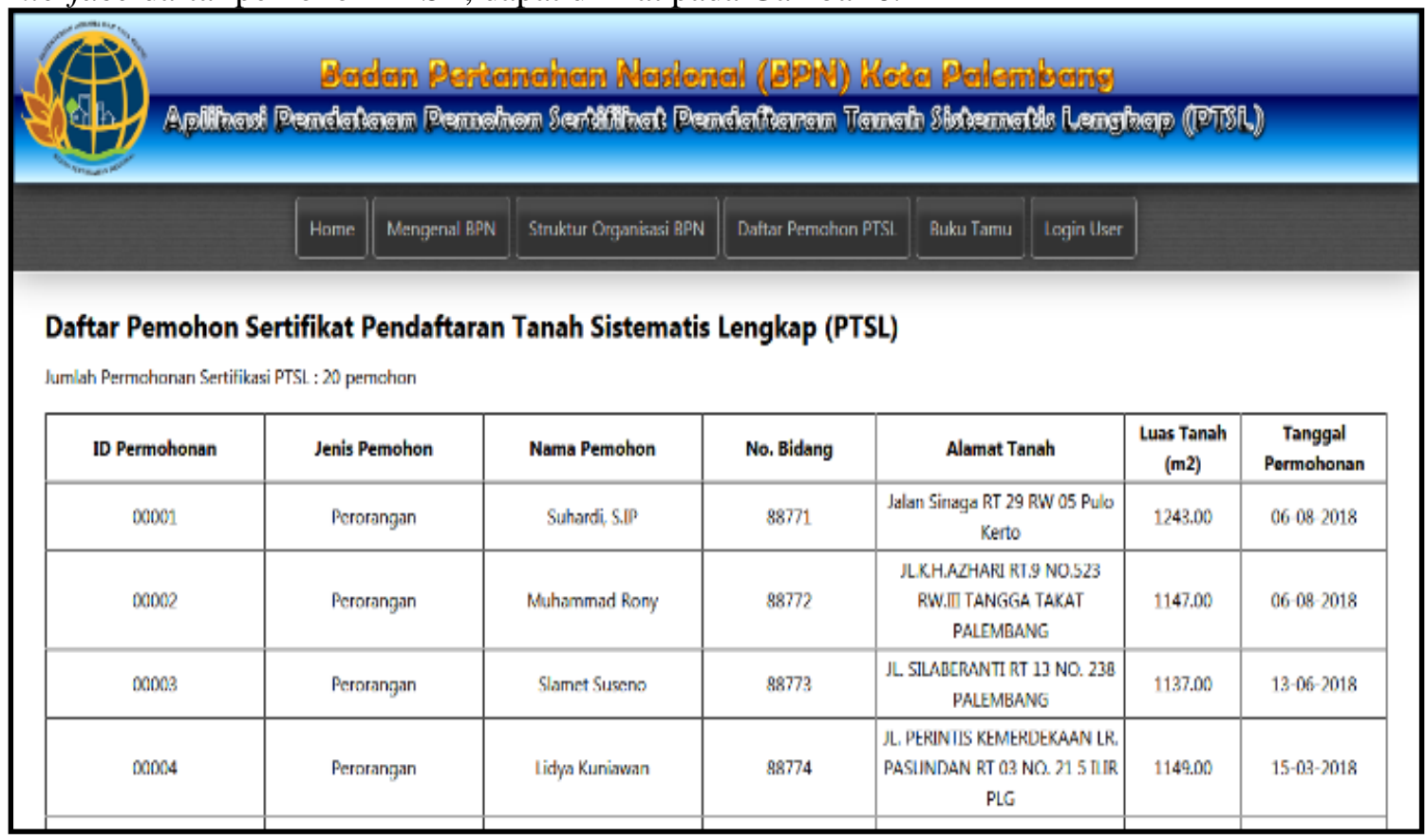

\section{Gambar 6 Daftar pemohon sertifikat PTSL}

Interface Daftar Pemohon PTSL menampilkan daftar pemohon sertifikasi Pendaftaran Tanah Sistematis Lengkap (PTSL) yang telah terdaftar sampai saat ini lengkap dengan alamat tanah, luas tanah dan tanggal permohonan diajukan. Tampilannya disajikan pada Gambar 6.

2. Interface buku tamu

Halaman buku Tamu menyediakan formulir buku tamu yang dapat diisi oleh pengunjung untuk memberikan informasi, masukan, saran dan kritik yang ditujukan ke BPN Palembang, dapat dilihat pada Gambar 7. Pengunjung harus mengisi nama lengkap, alamat e-mail, dan masukan/saran/kritik.

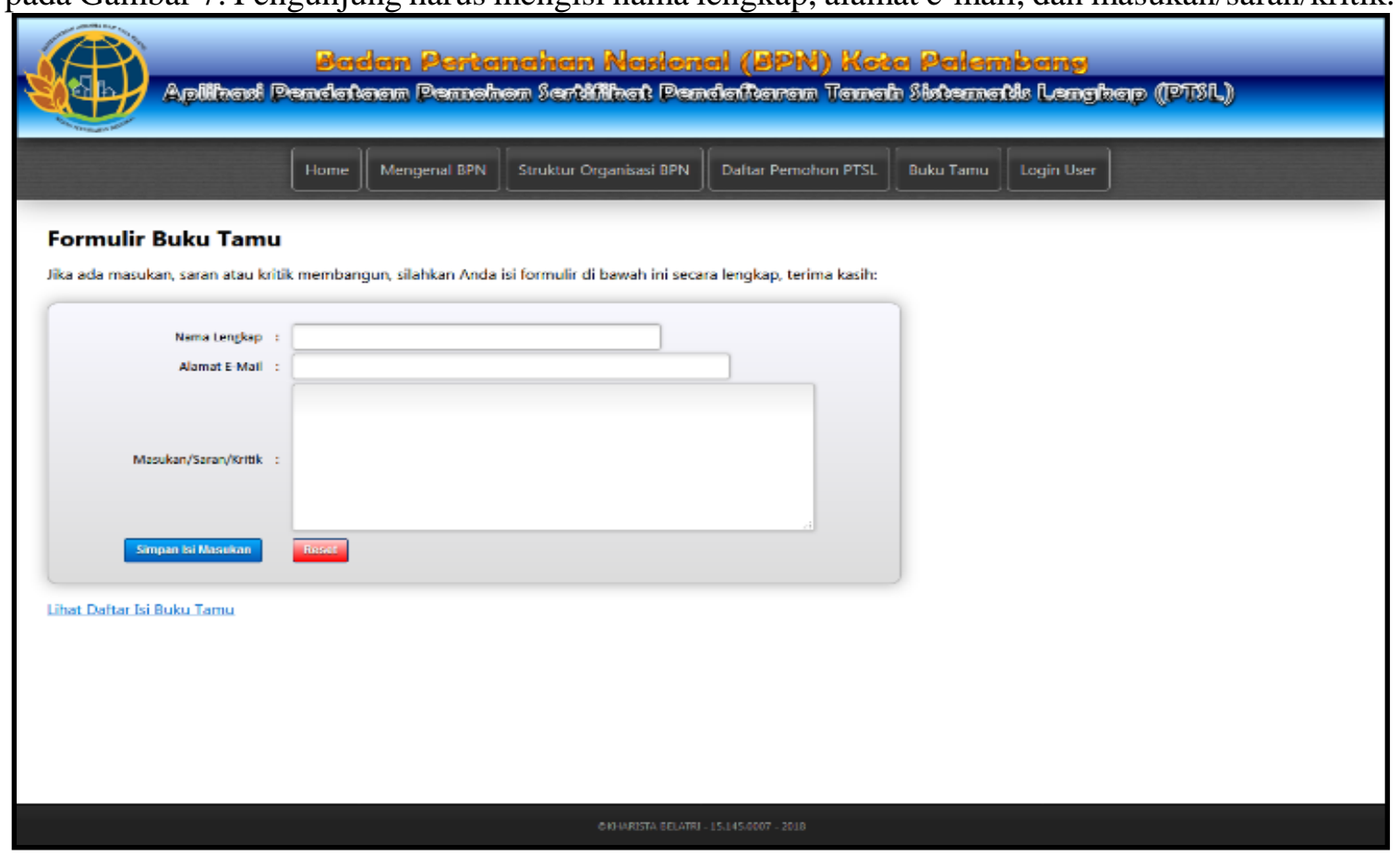

Gambar 7 Interface form buku tamu 


\section{Interface Login}

Fasilitas login dapat diakses oleh administrator atau Pekerja Tidak Tetap (PTT) sesuai dengan hak akses yang sudah diberikan untuk masing-masing user yang dapat dilihat pada Gambar 8 .

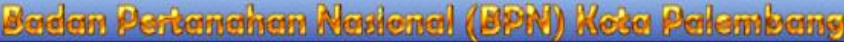

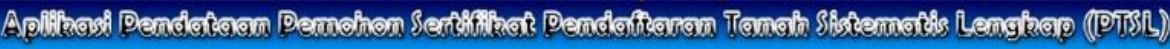

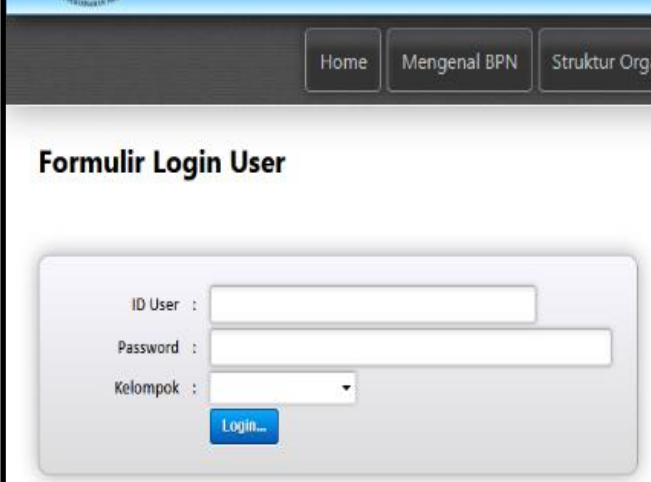

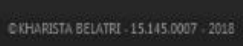

4. Interface utama administrator PTSL

Gambar 8 Login

Pada interface administrator PTSL ini mempunyai fasilitas ganti password, melihat isi data administrator, melihat isi data PTT, melihat daftar buku tamu, melihat daftar pemohon PTSL, dan logout. Dapat dilihat pada Gambar 9.

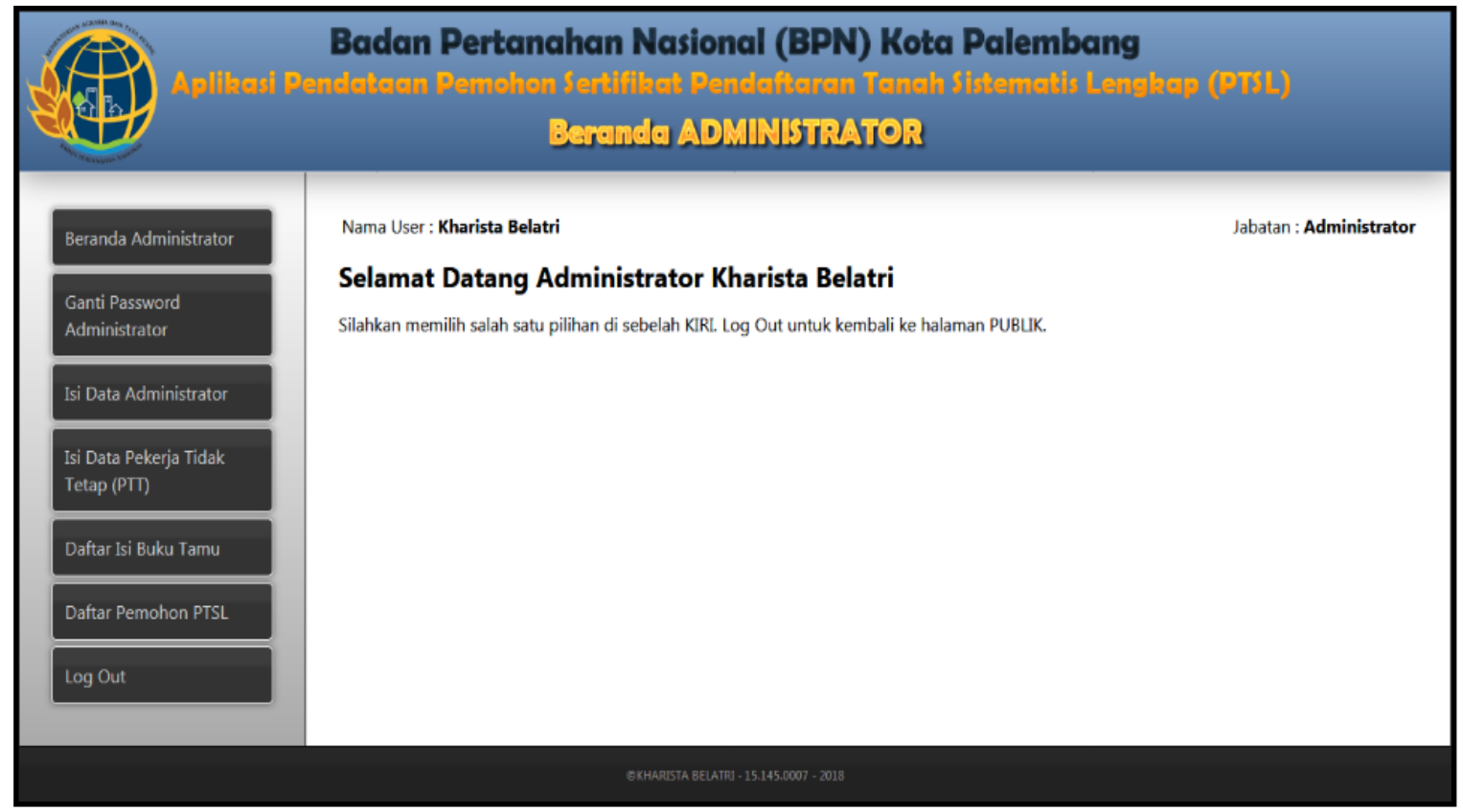

5. Interface data buku tamu

\section{Gambar 9 Tampilan utama administrator PTSL}

Pada data buku tamu ini ditampilkan tabel yang berisi daftar isian pengunjung website yang mengisi buku tamu. Di sebelah kanan ada tombol hapus jika administrator ingin menghapus record buku tamu tersebut. Administrator dapat membaca komentar, masukan, saran, atau kritik yang ditulis oleh pengunjung web pada halaman ini. Tampilan halaman daftar isi buku tamu dapat dilihat pada Gambar 10. 


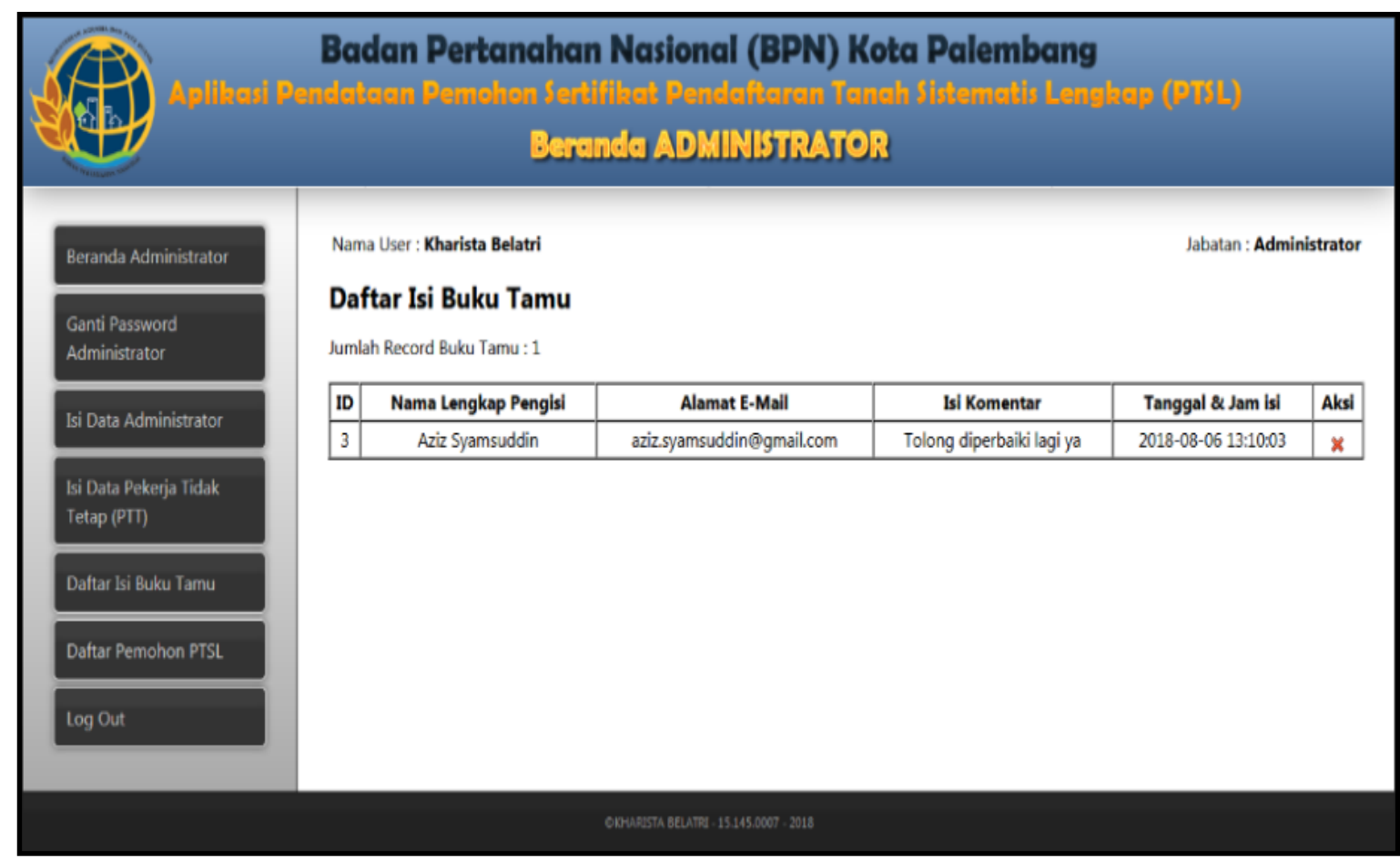

Gambar 10 Interface data buku tamu pada administrator PTSL

6. Interface data pemohon sertifikasi PTSL

Halaman Daftar Pemohon Sertifikat PTSL menampilkan tabel yang berisi daftar pemohon sertifikat Pendaftaran Tanah Sistematis Lengkap (PTSL) Pada Kantor Badan Pertanahan Nasional (BPN) Kota Palembang. Melalui halaman ini administrator dapat melihat daftar pemohon sertifikat PTSL yang sedang diproses sertifikatnya atau proses pembuatan sertifikatnya sudah selesai. Tampilan halaman daftar pemohon sertifikat PTSL dapat dilihat pada Gambar 11.

\begin{tabular}{|c|c|c|c|c|c|c|c|}
\hline Beranda Administrator & $\begin{array}{l}\text { Badan Per } \\
\text { Idotacin Pem }\end{array}$ & $\begin{array}{l}\text { nahan } \mathbf{N} \\
\text { Ben Sertifitin }\end{array}$ & 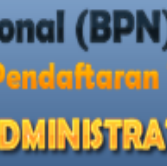 & $\begin{array}{l}\text { lota Pal } \\
\text { ich Sister } \\
\text { is }\end{array}$ & $\begin{array}{l}\text { embang } \\
\text { notis Lenghep ( }\end{array}$ & PTSL) & \\
\hline Beranda Administrator & \multicolumn{7}{|c|}{$\begin{array}{l}\text { Nama User : Kharista Belatri } \\
\text { Daftar Permohonan Sertifikasi PTSL } \\
\text { Jumlah Permohonan Sertifikasi PTSL: }\end{array}$} \\
\hline Isi Data Administrator & ID Permohonan & Jenis Pemohon & Nama Pemohon & No. Bidang & Alamat Tanah & $\begin{array}{l}\text { Luas } \\
\text { Tanah } \\
\text { (m2) }\end{array}$ & $\begin{array}{c}\text { Tanggal } \\
\text { Permohonan }\end{array}$ \\
\hline $\begin{array}{l}\text { Isi Data Pekerja Tidak } \\
\text { Tetap (PTT) }\end{array}$ & 00001 & Perorangan & Suhardi, S.IP & 88771 & $\begin{array}{c}\text { Jalan Sinaga RT } 29 \text { RW } \\
05 \text { Pulo Kerto }\end{array}$ & 1243.00 & 06-08-2018 \\
\hline Daftar Isi Buku Tarnu & 00002 & Perorangan & Muhammad Rony & 88772 & \begin{tabular}{|c|} 
ULK.K.AZHARI RT.9 \\
NO.523 RW.II TANGGA \\
TAKAT PALEMBANG
\end{tabular} & 1147.00 & 06-08-2018 \\
\hline Daftar Pemohon PISL & 00003 & Perorangan & Slamet Suseno & 88773 & \begin{tabular}{|l|} 
JL. SILABERANTI RT 13 \\
NO. 238 PALEMBANG
\end{tabular} & 1137.00 & $13-06-2018$ \\
\hline $\log$ Out & 00004 & Perorangan & Lidya Kuniawan & 88774 & \begin{tabular}{|c|} 
U. PERINTIS \\
KEMERDEKAAN LR. \\
PASUNDAN RT 03 NO.
\end{tabular} & 1149.00 & $15-03-2018$ \\
\hline
\end{tabular}

Gambar 11 Interface data pemohon sertifikat PTSL pada administrator PTSL

7. Interface utama PTT

Pada interface PTT ini mempunyai fasilitas ganti password, isi data PTSL melihat data PTSL, daftar data PTT, cari data PTSL, laporan status data PTSL, laporan bulanan data PTSL, dan logout yang dapat dilihat pada Gambar 12.

Amalia, Sistem Pendaftaran Tanah Sistematis Lengkap Pada Badan Pertanahan Nasional (BPN) Kota Palembang 


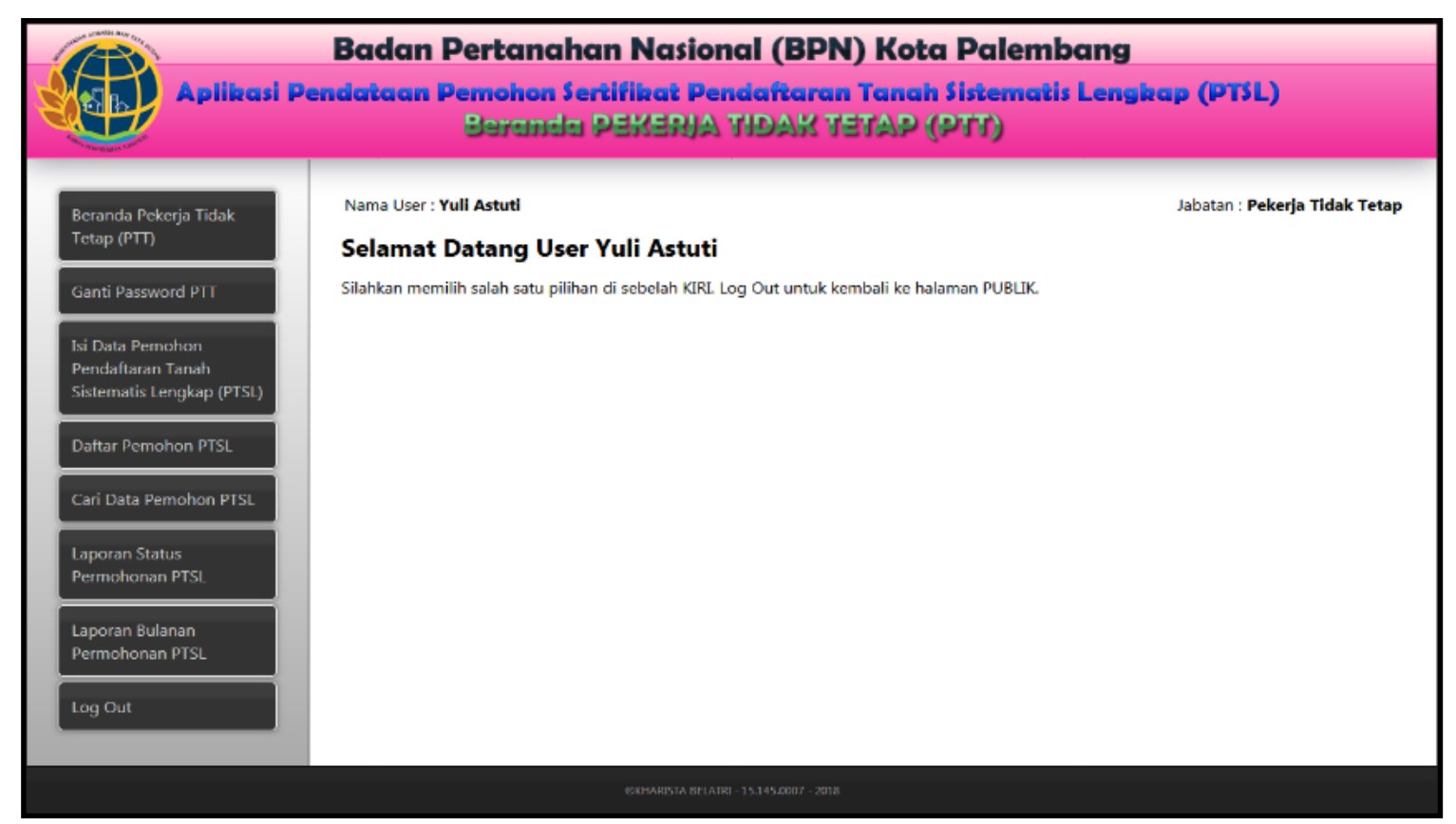

\section{Gambar 12 Interface beranda Pekerja Tidak Tetap (PTT)}

8. Interface formulir pemohonan sertifikat PTSL,

Halaman isi data pemohon sertifikat PTSL disediakan bagi PTT untuk mengisi data pemohon sertifikat PTSL baru. Formulir yang disediakan dibagi dalam 3 tab yaitu tab Pemohon, tab Tanah, dan tab Petugas. Kolom-kolom (field) pada ketiga tab ini harus diisi lengkap. Tampilan halaman isi data pemohon sertifikat PTSL disajikan pada Gambar 13.

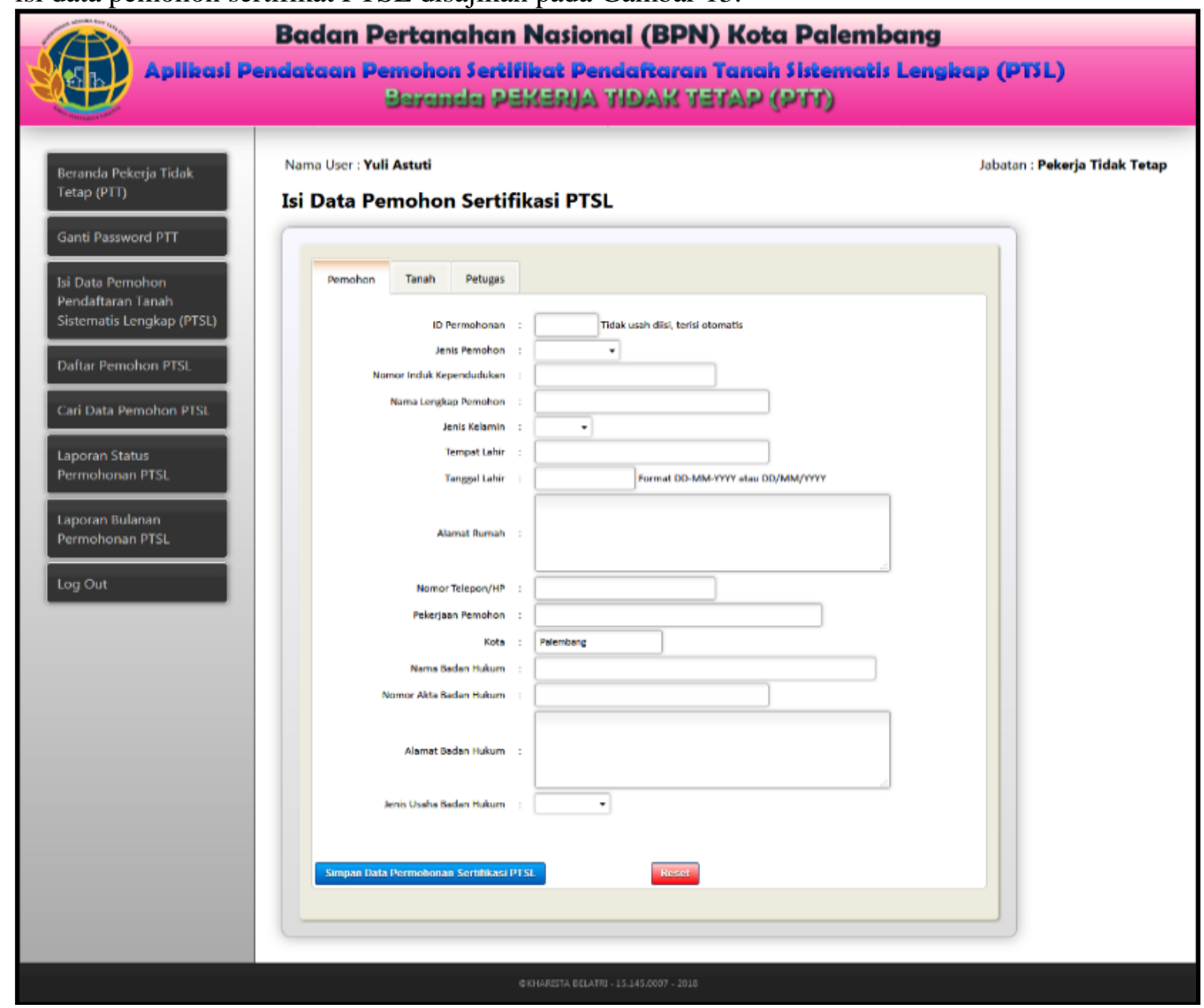

Gambar 13 Interface formulir pemohonan sertifikat PTSL

Amalia, Sistem Pendaftaran Tanah Sistematis Lengkap Pada Badan Pertanahan Nasional (BPN) Kota Palembang 
9. Interface data pemohon sertifikat PTSL

Halaman daftar pemohon sertikat PTSL menampilkan tabel yang berisi daftar pemohon sertifikat PTSL yang telah mengajukan permohonan sertifikasi PTSL atas tanah yang dimilikinya. Tampilannya dapat dilihat pada Gambar 14.

\begin{tabular}{|c|c|c|c|c|c|c|c|c|c|c|}
\hline (1) Aplikws & $\begin{array}{r}\text { Badan Per } \\
\text { dotann Pem } \\
9\end{array}$ & 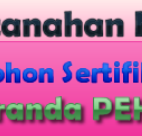 & $\begin{array}{l}\text { Jasional (B } \\
\text { 2at Pendafte } \\
\text { (ERIA WJDA }\end{array}$ & $\begin{array}{l}\text { PN) Ko } \\
\text { iran Tane } \\
\text { is TEYA? }\end{array}$ & $\begin{array}{l}\text { ta Palemba } \\
\text { ah Sistematis L } \\
\text { (PTJ) }\end{array}$ & $\begin{array}{l}\text { ng } \\
\text { englka }\end{array}$ & p (PTSL) & & & \\
\hline $\begin{array}{l}\text { Beranda Pekerja Tidak } \\
\text { Tetap (PTT) }\end{array}$ & \multirow{2}{*}{\multicolumn{6}{|c|}{$\begin{array}{l}\text { Nama User : Yuli Astuti } \\
\text { Daftar Permohonan Sertifikasi PTSL } \\
\text { Jumlah Permohonan : } 20 \text { Permohonan }\end{array}$}} & \multicolumn{4}{|c|}{ Jabatan : Pekerja Tidak Tetar } \\
\hline Ganti Password PTT & & & & & & & & & & \\
\hline \multirow{2}{*}{$\begin{array}{l}\text { Isi Data Pemohon } \\
\text { Pendaftaran Tanah } \\
\text { Sistematis Lengkap (PTSL) }\end{array}$} & ID Permohonan & Jenis Pemohon & Nama Pemohon & No. Bidang & Alamat Tanah & $\begin{array}{l}\text { Luas } \\
\text { Tanah }\end{array}$ & \begin{tabular}{|c|} 
Tanggal \\
Permohonan
\end{tabular} & \multicolumn{3}{|c|}{ Aksi } \\
\hline & 00016 & Perorangan & $\begin{array}{l}\text { Rezky Octora } \\
\text { Amalia }\end{array}$ & 88786 & \begin{tabular}{|c|} 
JL. SUKA BANGUN II \\
RT.34 RW 05 NO. \\
2168 PALEMBANG
\end{tabular} & 752.00 & $11-12-2018$ & B & $x$ & \\
\hline Cari Data Pemohon PTSL & 00007 & Perorangan & Ummi Hanny & 88777 & \begin{tabular}{|l|} 
JL. DI PANJATTAN \\
LRG. KERAMAT RT22 \\
RW 04 NO 41 \\
PALEMBANG
\end{tabular} & 873.00 & 17-11-2018 & B & x & \\
\hline $\begin{array}{l}\text { Laporan Status } \\
\text { Permohonan PTSL }\end{array}$ & 00006 & Perorangan & \begin{tabular}{|c|} 
Diany Putri Pratiwi \\
$\mathrm{s}$
\end{tabular} & 88776 & \begin{tabular}{|l|} 
JL.SILABERANTI RT.13 \\
NO.238 PALEMBANG
\end{tabular} & 1026.00 & 16-11-2018 & $B$ & x & \\
\hline $\begin{array}{l}\text { Laporan Bulanan } \\
\text { Permohonan PTSL }\end{array}$ & 00015 & Perorangan & Ardianda & 88785 & \begin{tabular}{|c|} 
JL.PERINTIS \\
KEMERDEKAAN LRG. \\
WIRAGUNA RT.21 \\
NO.55 PALEMBANG \\
30114
\end{tabular} & 892.00 & $25-10-2018$ & $B$ & $x$ & \\
\hline \multirow{4}{*}{ Log Out } & 00018 & Perorangan & Grevita Nanda Arta & 88788 & $\begin{array}{l}\text { JL. KAPT. ABDULLAH } \\
\text { SEI KEDUKAN NO. } 20 \\
\text { RT.06 MUBA PLAJU }\end{array}$ & 522.00 & 19-10-2018 & $B$ & $x$ & \\
\hline & 00013 & Perorangan & $\begin{array}{l}\text { Muhammad Dwi } \\
\text { Fariyanto }\end{array}$ & 88783 & $\begin{array}{l}\text { JL.A.YANI LR.A.KADIR } \\
\text { NO.56 PALEMBANG }\end{array}$ & 1212.00 & 04-10-2018 & B & x & \\
\hline & 00008 & Perorangan & $\begin{array}{l}\text { Muhammad } \\
\text { Febriansyah }\end{array}$ & 88778 & \begin{tabular}{|c|} 
JL.MAYOR SALM \\
BATUBARA LORONG \\
PENDOPO NO.132 \\
RT.02/01 PALEMBANG
\end{tabular} & 872.00 & 07-09-2018 & B & x & \\
\hline & 00001 & Perorangan & Suhardi, S.IP & 88771 & $\begin{array}{l}\text { Jalan Sinaga RT } 29 \\
\text { RW } 05 \text { Pulo Kerto }\end{array}$ & 1243.00 & 06-08-2018 & B & $x$ & \\
\hline
\end{tabular}

\section{Gambar 14 Interface data pemohonan sertifikat PTSL}

10. Interface laporan status pemohon sertifikat PTSL

Interface laporan status permohonan pembuatan sertifikat PTSL menampilkan laporan status permohonan sertifikat PTSL apakah sedang Dalam Proses atau sudah Selesai. dapat dilihat pada Gambar 15.

\begin{tabular}{|c|c|c|c|c|c|c|c|c|c|}
\hline \multicolumn{10}{|c|}{ 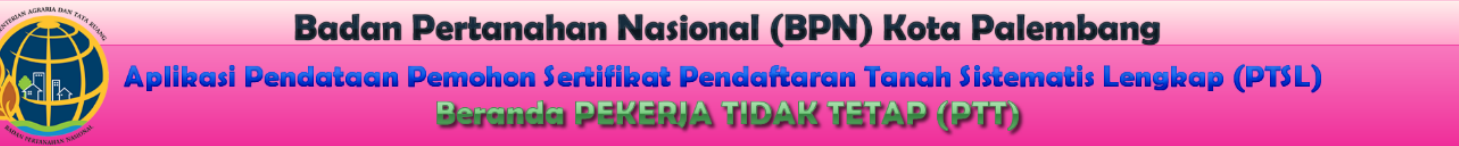 } \\
\hline $\begin{array}{l}\text { Beranda Pekerja Tidak } \\
\text { Tetap (PTT) } \\
\text { Ganti Password PTT }\end{array}$ & \multicolumn{9}{|c|}{$\begin{array}{l}\text { Nama User : Yuli Astuti } \\
\text { Laporan Status Permohonan Sertifikat PTSL } \\
\text { Jumlah Permohonan : } 20 \text { Permohonan }\end{array}$} \\
\hline \multirow[t]{2}{*}{$\begin{array}{l}\text { Isi Data Pemohon } \\
\text { Pendaftaran Tanah } \\
\text { Sistematis Lengkap (PTSL) }\end{array}$} & $\begin{array}{c}\text { ID } \\
\text { Permohonan }\end{array}$ & $\begin{array}{c}\text { Jenis } \\
\text { Pemohon }\end{array}$ & NIK & $\begin{array}{c}\text { Nama } \\
\text { Pemohon }\end{array}$ & Alamat Tanah & $\begin{array}{l}\text { Luas } \\
\text { Tanah } \\
(\mathrm{m} 2)\end{array}$ & $\begin{array}{c}\text { Status } \\
\text { Permohonan }\end{array}$ & $\begin{array}{l}\text { Tanggal } \\
\text { Status }\end{array}$ & $\begin{array}{l}\text { Nama } \\
\text { Petugas }\end{array}$ \\
\hline & 00001 & Perorangan & 012011828091978 & Suhardi, S.IP & $\begin{array}{c}\text { Jalan Sinaga RT } 29 \text { RW } 05 \\
\text { Pulo Kerto }\end{array}$ & 1243.00 & Dalam Proses & 2018-08-06 & \begin{tabular}{|c|} 
Manatar \\
Pasaribu, S.E.
\end{tabular} \\
\hline Cari Data Pemohon PTSL & 00002 & Perorangan & 012011828091978 & $\begin{array}{c}\text { Muhammad } \\
\text { Rony }\end{array}$ & $\begin{array}{l}\text { JL.K.H.AZHARI RT.9 } \\
\text { NO.523 RW.III TANGGA } \\
\text { TAKAT PALEMBANG }\end{array}$ & 1147.00 & Dalam Proses & 2018-08-06 & $\begin{array}{c}\text { Ridwan } \\
\text { Hanafiah, S.H. }\end{array}$ \\
\hline Laporan Status & 00003 & Perorangan & 012011828091978 & $\begin{array}{l}\text { Slamet } \\
\text { Suseno }\end{array}$ & $\begin{array}{l}\text { JL. SILABERANTI RT } 13 \\
\text { NO. } 238 \text { PALEMBANG }\end{array}$ & 1137.00 & Dalam Proses & 2018-06-13 & Yuliana, S.H. \\
\hline $\begin{array}{l}\text { Laporan Bulanan } \\
\text { Permohonan PTSL }\end{array}$ & 00004 & Perorangan & 012011828091978 & $\begin{array}{l}\text { Lidya } \\
\text { Kuniawan }\end{array}$ & \begin{tabular}{|c|} 
JL. PERINTIS \\
KEMERDEKAAN LR. \\
PASUNDAN RT 03 NO. 21 \\
5 ILIR PLG
\end{tabular} & 1149.00 & Dalam Proses & 2018-03-15 & $\begin{array}{c}\text { Muhammad } \\
\text { Akbar, S.H. }\end{array}$ \\
\hline Log Out & 00005 & Perorangan & 012011828091978 & $\begin{array}{c}\text { Ahmad } \\
\text { Kumroni, M.Si. }\end{array}$ & \begin{tabular}{|c|} 
JL. SWAKARYA RT.142 \\
RW.08 NO.2497 KEMANG \\
AGUNG PALEMBANG
\end{tabular} & 560.00 & Dalam Proses & 2018-08-06 & $\begin{array}{c}\text { Manatar } \\
\text { Pasaribu, S.E. }\end{array}$ \\
\hline
\end{tabular}

Gambar 15 Interface laporan status data pemohonan sertifikat PTSL

Amalia, Sistem Pendaftaran Tanah Sistematis Lengkap Pada Badan Pertanahan Nasional (BPN) Kota Palembang 
11. Interface pencarian data pemohon sertifikat PTSL

Interface pencarian data pemohon sertifikat PTSL disediakan bagi PTT untuk mencari data pemohon PTSL yang ada jika data pemohon sudah sangat banyak. Pencarian dapat dilakukan melalui nama pemohon, alamat tanah, atau nama petugas. Tampilan halaman pencarin dapat dilihat pada Gambar 16.

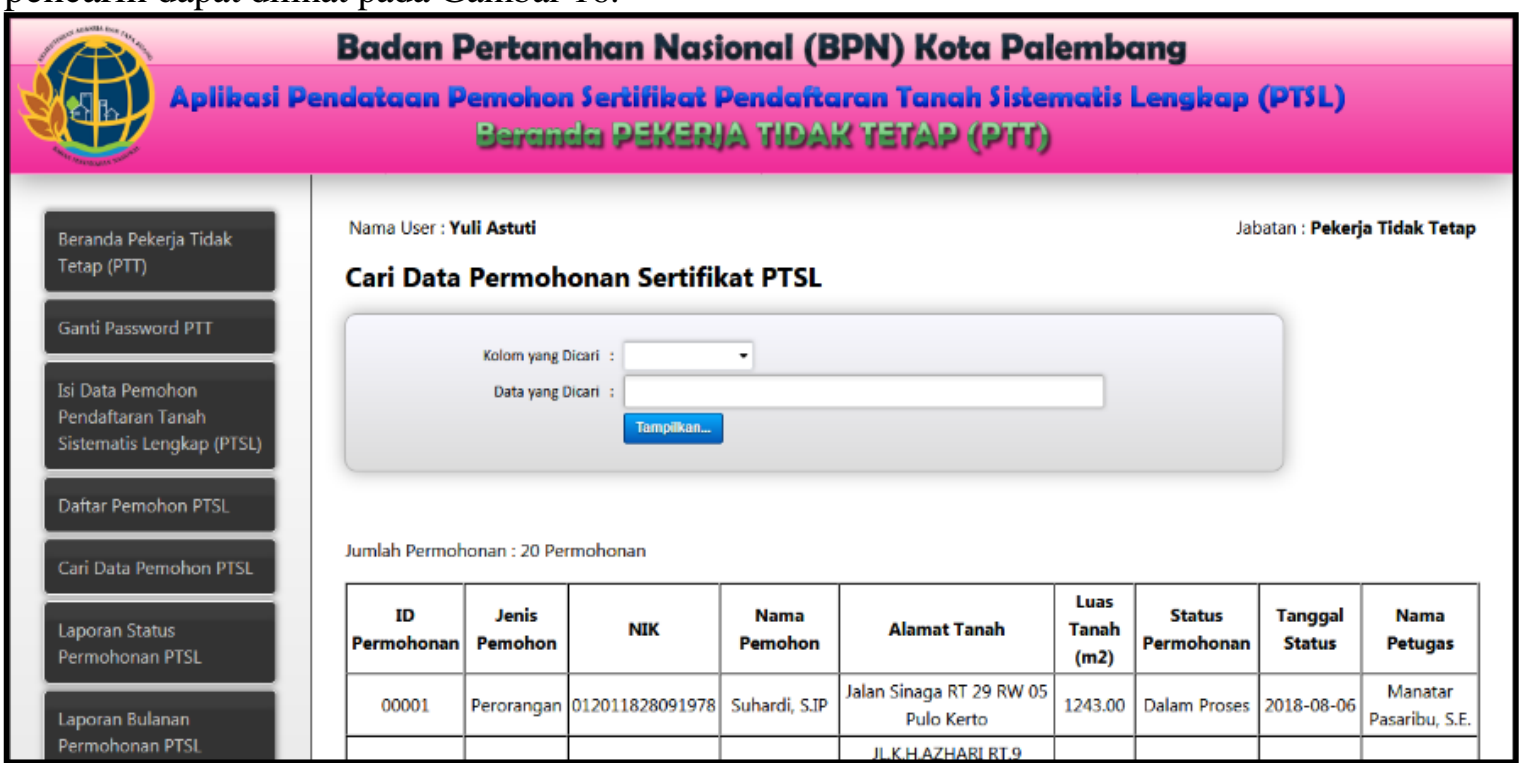

Gambar 16 Interface pencarian data pemohonan sertifikat PTSL

12. Interface laporan bulanan pemohon sertifikat PTSL

Interface Laporan Bulanan Daftar Pemohon Sertifikat PTSL menyediakan fasilitas untuk melihat daftar pemohon sertifikat PTSL bulanan. Pada halaman ini PTT dapat memilih bulan dan tahun yang dikehendaki dan menekan tombol Tampilkan. Tampilannya dapat dilihat pada Gambar 17.

\begin{tabular}{|c|c|c|c|c|c|c|c|c|}
\hline \multicolumn{9}{|c|}{ 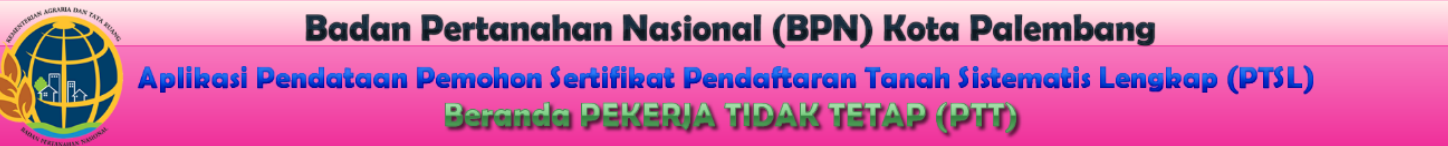 } \\
\hline $\begin{array}{l}\text { Beranda Pekerja Tidak } \\
\text { Tetap (PTT) }\end{array}$ & \multicolumn{6}{|c|}{$\begin{array}{l}\text { Nama User: Yuli Astuti } \\
\text { Laporan Bulanan Permohonan Sertifikat PTSL }\end{array}$} & \multicolumn{2}{|c|}{ an : Pekerja Tidak Tetap } \\
\hline $\begin{array}{l}\text { Isi Data Pemohon } \\
\text { Pendaftaran Tanah } \\
\text { Sistematis Lengkap (PTSL) }\end{array}$ & \multicolumn{3}{|c|}{$\begin{array}{ll}\text { Bulan Permohonan : } & \text { Seluruhnya }- \\
\text { Tahun Permohonan : } & 2018 \\
& \text { Tampilikan... }\end{array}$} & & & & & \\
\hline Daftar Pemohon PTSL & \multicolumn{8}{|c|}{ Jumlah Permohonan : 20 permohonan } \\
\hline Cari Data Pemohon PTSL & ID Permohonan & Jenis Pemohon & Nama Pemohon & No. Bidang & Alamat Tanah & $\begin{array}{l}\text { Luas } \\
\text { Tanah }\end{array}$ & \begin{tabular}{|c|} 
Tanggal \\
Permohonan
\end{tabular} & $\begin{array}{c}\text { Status } \\
\text { Permohonan }\end{array}$ \\
\hline $\begin{array}{l}\text { Laporan Status } \\
\text { Permohonan PTSL }\end{array}$ & 00001 & Perorangan & Suhardi, S.IP & 88771 & $\begin{array}{l}\text { Jalan Sinaga RT } 29 \\
\text { RW } 05 \text { Pulo Kerto }\end{array}$ & 1243.00 & 06-08-2018 & Dalam Proses \\
\hline $\begin{array}{l}\text { Laporan Bulanan } \\
\text { Permohonan PTSL }\end{array}$ & 00002 & Perorangan & Muhammad Rony & 88772 & $\begin{array}{l}\text { JL.K.H.AZHARI RT.9 } \\
\text { NO.523 RW.III } \\
\text { TANGGA TAKAT }\end{array}$ & 1147.00 & 06-08-2018 & Dalam Proses \\
\hline
\end{tabular}

\subsection{Pengujian}

\section{Gambar 17 Interface laporan bulanan data pemohonan sertifikat PTSL}

Pengujian interface sistem pendaftaran tanah sistematis lengkap pada badan pertanahan nasional (BPN) kota Palembang menggunakan black box dengan hasil sebagai berikut:

1. Interface materi digital siswa: materi digital nampil pada halaman awal aplikasi tanpa melakukan login, kesimpulan hasil pengujian diterima

2. Interface Daftar Pemohon PTSL menampilkan daftar pemohon sertifikasi Pendaftaran Tanah Sistematis Lengkap (PTSL), kesimpulan hasil pengujian diterima.

3. Interface buku tamu merupkan form buku tamu yang dapat diisi oleh pengunjung tanpa login, kesimpulan hasil pengujian diterima.

Amalia, Sistem Pendaftaran Tanah Sistematis Lengkap Pada Badan Pertanahan Nasional (BPN) Kota Palembang 
4. Interface login dapat diakses oleh administrator atau Pekerja Tidak Tetap (PTT) yang memiliki hak akses, kesimpulan hasil pengujian diterima.

5. Interface utama administrator PTSL merupakan halaman administrator setelah berhasil login, kesimpulan hasil pengujian diterima.

6. Interface data buku tamu merupakan menampilkan data-data tamu, kesimpulan hasil pengujian diterima.

7. Interface data pemohon sertifikasi PTSL merupakan daftar pemohon sertifikat Pendaftaran Tanah Sistematis Lengkap (PTSL) Pada Kantor Badan Pertanahan Nasional (BPN) Kota Palembang, kesimpulan hasil pengujian diterima.

8. Interface utama PTT adalah halaman PTT setelah berhasil login, kesimpulan hasil pengujian diterima.

9. Interface formulir pemohonan sertifikat PTSL merupakan form permohoman sertifikat PTSL yang diisi oleh PTT, kesimpulan hasil pengujian diterima.

10. Interface data pemohon sertifikat PTSL merupakan data pemohon sertifikat PTSL yang telah mengajukan permohonan sertifikasi PTSL, kesimpulan hasil pengujian diterima.

11. Interface laporan status pemohon sertifikat PTSL merupkan laporan status permohonan sertifikat PTSL, kesimpulan hasil pengujian diterima.

12. Interface pencarian data pemohon sertifikat PTSL merupkan mencari data pemohon PTSL, kesimpulan hasil pengujian diterima.

\subsection{Deployment}

Pada tahap deployment merupkan tahap penyebaran dengan cara memberikan pelatihan kepada penggunkan terutama administrator dan PTT, bagaiman cara menggunakannya. Penyebaran melalui media sosial warga kota Palembang untuk pemohon sertifikat Pendaftaran Tanah Sistematis Lengkap (PTSL). Tujuan penyembaran sistem ini supaya warga kota Palembang dapat dengan mudah melakukan pemohanan PTSL. Sistem ini mempermudah dalam proses pengajuan PTSL karena dapat diakses dimanapun secara online.

\section{KESIMPULAN}

Berdasarkan uraian yang telah dikemukakan, maka dapat dikesimpulan bahwa penelitian ini menghasilkan penerapan sistem Pendataan Pemohon Sertifikat PTSL pada Kantor BPN Kota Palembang dengan berbasis web, yang mempermudah dan pempercepat kerja karyawan dalam proses Pendaftaran Tanah Sistematis Lengkap (PTSL) pada Kantor Badan Pertanahan Nasional (BPN). Tampilan utama dari sistem ini adalah tampilan publik, tampilan administrator, dan tampilan Pegawai Tidak Tetap (PTT). Adapun saran dari peneliti, agar sistem dapat dikembangkan kearah mobile atau androit supaya lebih mudah dan simple dalam mengakses dan menggunakan sistem tersebut.

\section{REFERENSI}

[1] W. Hidayat, "Kementrian Komunikasi dan Informatika Republik Indonesia," 2017.

[2] M. P. Rakyat and R. I. MPR, Undang-Undang Dasar Negara Republik Indonesia Tahun 1945. Sekretariat tsb., 2006.

[3] B. P. H. Nasional, "Hak Menguasai Negara di Bidang Pertanahan." Jakarta, 2015.

[4] D. Anastasia and L. Setiawati, "Sistem Informasi Akuntansi: Perancangan, Proses dan Penerapan," CV. ANDI OFFSET. Yogyakarta, 2011.

[5] M. A. Dita and I. W. Putra, "Pengaruh penerapan sistem informasi akuntansi terhadap kinerja karyawan dengan integritas karyawan sebagai variabel pemoderasi," E-Jurnal Akunt., pp. 614640, 2016.

[6] M. B. Romney and P. J. Steinbart, "Sistem informasi akuntansi," Terjem. Dewi Fitriasari, dan Deny Aros Kewary, Ed. Sembilan, Buku Satu, Salemba Empat, Jakarta, 2004.

[7] H. Sofyan, Y. Fauziah, and I. G. Y. Negara, "Pengembangan Aplikasi Layanan Pertanahan Berbasis Web pada Kantor BPN (Badan Pertanahan Nasional) Kabupaten Badung," in Seminar Nasional Informatika (SEMNASIF), 2015, vol. 1, no. 5. 
[8] B. Bahram, T. Taufiq, and R. Rahmi, "Aplikasi Permohonan Surat Izin Tempat Usaha Berbasis Web Di Kantor Kelurahan,” JUTISI, vol. 4, no. 1, 2015.

[9] B. Waspodo, A. N. Fajar, and N. H. Prayitno, "Sistem informasi pelayanan izin mendirikan bangunan dan peruntukan penggunaan tanah pada badan penanaman modal dan pelayanan perizinan kabupaten sumedang," Stud. Inform. J. Sist. Inf., vol. 8, no. 2, 2015.

[10] F. E. Puspitasari, "Rancang Bangun Sistem Informasi Sertipikasi Tanah Kantor Pertanahan Kabupaten Kebumen.” UNIVERSITAS NEGERI SEMARANG, 2015.

[11] I. Solikin, "DESAIN APLIKASI PEDATAAN PASIEN PADA PUSKESMAS TUGU JAYA KABUPATEN OKI," J. Betrik, vol. 12, no. 3, pp. 166-174, 2017.

[12] R. S. Pressman and R. P. Lunak, "pendekatan Buku 1." Yoyakarta: Andi, 2015.

[13] S. Tarsito, "Metode Penelitian Kuantitatif, Kualitatif dan R\&D," Alf. Bandung, 2014.

[14] D. F. Murad and N. Kusniawati, "Aplikasi Intelligence Website untuk Penunjang Laporan PAUD pada Himpaudi Kota Tangerang," CCIT J., vol. 7, no. 1, pp. 44-58, 2013.

[15] N. E. Cagiltay, G. Tokdemir, O. Kilic, and D. Topalli, "Performing and analyzing non-formal inspections of entity relationship diagram (ERD)," J. Syst. Softw., vol. 86, no. 8, pp. 2184-2195, 2013. 